\title{
A Review of Corporate Governance and Firm Performance
}

\author{
Abid Rasheed \\ Lecturer, School of Accounting and Finance, University of Central Punjab \\ abid.rasheed@ucp.edu.pk
}

Zara Nisar

MS Scholar, School of Accounting and Finance, University of Central Punjab zaranisar1@gmail.com

\begin{abstract}
Corporate governance is the way by which organizations are governed and run. In the present age, corporate governance has been emerged as an important concept. After the financial crises, the importance of corporate governance has been increasing. Many studies have been performed on the relationship of corporate governance and firm performance. Corporate governance, besides other issues, deals with agency problem. Agency problem arises because of the nature of relationship between shareholders and the directors of an organization. In this study, a review of the recent studies performed on the relationship of corporate governance and firm performance has been done. A content analysis approach has been used to study the patterns identified in previous studies.

Keywords: Corporate governance, firm performance, agency problem, content analysis
\end{abstract}

\section{Introduction}

Corporate governance - the system by which companies are directed and controlled (Cadbury, 2002) — has emerged as an important concept. A wide research has been conducted on the effect of corporate governance on the firm's financial performance. This research has been focused on the emerging markets as well, because of the recent financial crises and collapses. The concept of corporate governance focuses on the agency problem along with other theories and areas such as corporate social responsibility, stewardship theory, ethics etc. Agency problem is the problem that lies between the shareholders, who are the principal, and the managers of the company, who act as the agents of the shareholders. The issue is that the objectives and intentions of the agents might not be in line with the principals' lead to the agency problem.

The growing importance of corporate governance was the result of Enron scandal, Asian financial crisis, and the fall of WorldCom (Ng'eni, 2015). The recent financial crisis such as the financial crunch of 2008 has also contributed towards the growing importance of improvement of the corporate governance structure. It is mostly believed that the recent financial crisis has been the result of the weaknesses in the corporate governance structure which when put to practical test failed to serve the task of preventing the failures resulting from excessive risk taking (Kirkpatrick, 2009).

A good corporate governance structure can help an organization to prevent it from external and internal risks. It can help in

The current issue and full text archive of this journal is available at www.jraspublications.org/index.php/JRAS/issue/archive

Journal of Research in Administrative Sciences (JRAS)

VII(II), 14-24, ISSN: 2664-2433 safeguarding the interests of the shareholders. However, poor corporate governance structures can not only cause the individual firm's performance to deteriorate but also the market. It is argued that if on the macro-economic level the organizations are not well-governed and their corporate governance structures are not well in place, then the macro-economic objectives might not be achieved (Ganiyu \& Abiodun, 2012).

Corporate governance has an important impact on the financial performance of the firms. When there is a good corporate governance structure in place the confidence of the market increases in the firm which can lead to more investments and better financial performance of the company. A vast number of studies has been performed on the relationship of corporate governance and firm's financial performance, part of this research has been conducted on the emerging markets as well.

As there has been a lot of studies conducted on the relationship of corporate governance and firm's financial performance. There is a need to study the recent trends in the studies being performed in this area. For this study, a content analysis approach has been adopted to study the recent trend in the research being performed in the countries of India, Pakistan, Bangladesh and Russia regarding the relationship of corporate governance and firm's financial performance.

To this end this paper is organized as follows: First, we briefly review previous research on mission statement analysis to identify the major themes and findings. Second, we briefly discuss our data, research methods and our analytic approach which is followed by a discussion of our detailed analysis. Finally, we discuss the main insights of our findings. 


\section{Literature Review}

Many studies have been done on the relationship of corporate governance and firm performance. Yilmaz \& BuyukluI (2016) studied the effect of corporate governance variables on firm's performance and found that independent board members and leverage affect the firm's performance negatively and foreign ownership effects positively.

Lückerath-Rovers (2013) studied the relationship of presence and absence of women on board with the firm performance of Dutch companies. This study revealed that the fims having women on board perform better as compared to the firms with no or lesser number of women on boards.

Several reviews have examined the major trends and debates in corporate governance research. For example, Brown, Beekes and Verhoven (2011) in an extensive review of accounting and finance related research on corporate governance stresses on the importance of the ways of measurement of corporate governance, construction of corporate governance indices and the challenge faced by the scholars because of stickiness of corporate governance (Brown, Beekes, \& Verhoeven, 2011).

One of the reviews on corporate governance performed by Claessens and Yurtoglu (2013) reviews the research done on the corporate governance of emerging markets. Their study reveals that better corporate governance mechanisms leads to better performances of the firms. This study also reveals that when the governance of a country is weak, the coporate governance mechanism of the companies are less effective.

Ng'eni (2015), in another extensive review of previous research on the association between corporate governance and firm performance, found that corporate governance is one of the major factors affecting the firm's performance. Ng'eni (2015) further argues that previous research done on this topic can be divided into two broad categories i.e. focusing on single component and multiple components of corporate governance. The study found that in previous researches it was concluded that independent director's ratio and women director's ratio are positively related to firm performance. However, Weir and Lang (2000) found conflicting results and concluded that independent directors do not contribute positively towards firm performance. The review

Table 1

Titles of selected articles

No. Title

India

1 The Impact of Corporate Governance on the Profitability: An Empirical Study of Indian Textile Industry (Narwal \& Jindal, 2015)

2 Shareholder Types, Corporate Governance and Firm Performance: An Anecdote from Indian Corporate Sector (Rajput, 2015)

3 Corporate governance and firm performance in developing countries:

Evidence from India (Arora, Arora, Sharma, \& Sharma, 2016)

4 Corporate governance and firm performance in Indian listed it Companies (Kumar, 2016)

5 Impact of corporate governance practices on firm profitability: A study of selected industries in India (Goel \& Ramesh, 2016)

6 Corporate governance and performance of foreign firms in India (Bishnoi \& Sh, 2015)

7 Impact of corporate governance and financial parameters on profitability of the BSE 100 companies (Kumar, Kumar, Gupta, \& Sharma, 2017)

8 Corporate governance and firm's performance during subprime crisis: Evidence from Indian firms (Mohinder \& Sanjeev, 2015) Corporate governance, product market competition and firm also found that in most researches there existed a mixed relationship between board composition and firm performance. As the result of review performed by Ng'eni (2015) showed that there was a positive relationship between women on board and firm's performance. This result was in line with the review performed on the gender diversity element of corporate governance focusing on the presence of women on corporate boards and their relationship with firm performance (Terjesen, Sealy, \& Singh, 2009). The researchers found out in their review that the research on women on corporate boards is mainly focused on the improvement of corporate governance through using the talent of the whole capital pool available.

Corporate governance has gained much importance due to the financial crises. Part of this increased importance was owed to the Asian financial crisis. A review done on the corporate governance and Asian financial governance determined that during the financial crisis the companies were not run badly. But the main reason was that the rights of minority shareholders were not being protected and majority shareholders were in full control. Agency problems led to main problems. Weak and alternative corporate governance mechanisms have limited effectiveness in systems (Claessens \& Fan, 2002)

\section{Data and Methodology}

For this article a total of 32 articles were selected in which the relationship between corporate governance and firm performance was studied in the countries of India, Pakistan, Bangladesh and Russia. Most recent articles studying the effect of corporate governance on firm performance were selected. The articles were chosen through Google Scholar search engine which is one of the largest depositories of academic research. Since the Google Scholar search engine allows for journal specific search, articles published in journals having "corporate governance", "finance", "financial" or "management" in their titles were selected. Articles which were published after 2014 were given the highest priority but in case of Russia there were a very limited number of articles available on this topic thus, articles published during any past time were selected. The specific articles selected for the study are mentioned in Table 1.

\section{Independent Variables}

Board size, Non-executive directors in the board, Directors remuneration, Board meetings, Audit committee members

Return on equity, Return on assets, Tobin 's Q, Retail shareholding, Institutional shareholding, Government shareholding, Family shareholding, Foreign shareholding, Corporate shareholding, Size, Corporate Governance Index, Board Size, Age, Debt Equity Ratio

Board Size, Board Independence, CEO Duality, Institutional Ownership

Board Size, Board Independence, Board Diversity

Number of Meetings of Board of Directors, Number of Independent Directors on Board, Risk Management, Compliance and Ethics Committee, well defined Code of Ethics, Communication and Distribution of code of ethics, Legal cases pending against company, Whistle blower policy

Board Size, Board Independence, Audit Index, Board Index

Leverage, CG Score, Dividend per share, Market Capitalization

Ownership structure, CG Index which includes: Board structure index, CEO duality, Auditor index, Remuneration index, Disclosure index

Ownership structure, Leverage and Business group performance in India: An empirical inquiry (Pattanayak, 2008) 
10 Audit committee, corporate governance and firm performance: Empirical evidence from India (Bansal \& Sharma, 2016)

\begin{tabular}{|c|c|}
\hline \multicolumn{2}{|c|}{ Pakistan } \\
\hline 11 & $\begin{array}{l}\text { The effect of corporate governance practices on firm } \\
\text { performance: Evidence from Pakistan (Muhammad, Rehman, \& } \\
\text { Waqas, 2016) }\end{array}$ \\
\hline 12 & $\begin{array}{l}\text { Corporate governance and firm performance: A case study of } \\
\text { Karachi stock market (Khatab, Masood, Zaman, Saleem, \& } \\
\text { Saeed, 2011) }\end{array}$ \\
\hline 13 & $\begin{array}{l}\text { Corporate governance and performance (A case study for } \\
\text { Pakistani communication sector) (Yasser, 2011) }\end{array}$ \\
\hline 14 & $\begin{array}{l}\text { Corporate governance and performance: An analysis of } \\
\text { Pakistani listed firms (Yasser, 2011) }\end{array}$ \\
\hline 15 & $\begin{array}{l}\text { The relationship between corporate governance and firm } \\
\text { performance } \\
\text { (Evidence from textile sector of Pakistan) (Gul, Sajid, Khan, } \\
\text { Bukhari, \& Iqbal, 2011) }\end{array}$ \\
\hline 16 & $\begin{array}{l}\text { Impact of corporate governance on performance of firms: A } \\
\text { case study of cement industry in Pakistan (Cheema \& Din, } \\
\text { 2013) }\end{array}$ \\
\hline 17 & $\begin{array}{l}\text { Effects of corporate governance on organization performance: } \\
\text { Evidence from banking sector of Pakistan (Chughtai \& Tahir, } \\
\text { 2015) }\end{array}$ \\
\hline 18 & $\begin{array}{l}\text { Effect of corporate governance on performance of Microfinance } \\
\text { institutions: A case from Pakistan (Gohar \& Batool, 2015) }\end{array}$ \\
\hline 19 & $\begin{array}{l}\text { Corporate governance and firm performance: A case study of } \\
\text { Pakistan oil and gas companies listed in Karachi stock exchange } \\
\text { (Dar, Naseem, Niazi, \& Rehman, 2011) }\end{array}$ \\
\hline 20 & $\begin{array}{l}\text { Corporate governance and performance: An empirical evidence } \\
\text { from textile sector of Pakistan (Gull, Saeed, \& Abid, 2013) }\end{array}$ \\
\hline 21 & $\begin{array}{l}\text { Impact of corporate governance on firm performance: Evidence } \\
\text { from sugar mills of Pakistan (Latif, Shahid, Haq, Waqas, \& } \\
\text { Arshad, 2013) }\end{array}$ \\
\hline \multicolumn{2}{|c|}{ Bangladesh } \\
\hline 22 & $\begin{array}{l}\text { An empirical study on corporate governance and Islamic bank } \\
\text { performance: A case study of } \\
\text { Bangladesh (Ahmed, Ullah, Ahmed, \& Rahman, 2016) }\end{array}$ \\
\hline 23 & $\begin{array}{l}\text { The financial performance and corporate governance } \\
\text { disclosure: A study in the annual reports of listed companies of } \\
\text { Bangladesh (Rouf \& Abdur, 2012) }\end{array}$ \\
\hline 24 & $\begin{array}{l}\text { Corporate governance and bank performance: The case of } \\
\text { Bangladesh (Hoque, Islam, \& Ahmed, 2013) }\end{array}$ \\
\hline
\end{tabular}

Examining the relationship between corporate governance and bank

performance in Bangladesh (Islam, Sathye, \& Hu, 2015) Relationship between corporate governance and firm performance: A case study in Bangladesh (Habib, 2016)

27 Corporate governance, executive pay and firm performance: Evidence from Bangladesh (Rashid, 2013)

Russia

28 Corporate governance and firm performance in the oil and gas industry of Russia (Orazalin, Makarov, \& Ospanova, 2015)

Corporate governance and bank performance in emerging markets: Evidence from Russia and Ukraine (Love, 2015)

The corporate governance behavior and market value of Russian firms (Black B. , 2001)

Does corporate governance reform necessarily boost firm performance? recent evidence from Russia (Kuznecovs \& Pal, 2012)

32 Corporate governance and firms' market values: Time series evidence from Russia (Black, Love, \& Rachinsky, 2006)
Audit committee, CEO duality, shareholding, board composition and board size

Board composition, board size, CEO duality and audit committee

Firm size, leverage and growth

Shareholders rights, equity structure, board composition and transparency \& disclosures.

Family ownership, board composition, director's qualification, independent directors, board meetings and leadership structure

Board size, CEO duality, total block holding, institutional block holding, board composition and inside block holding

Board size, CEO duality and family ownership

Board size, board meeting, non-executive director, bank size, leverages.

Board size, CEO duality, female directors and firm size

Board size, CEO duality, Audit committee and Annual general meeting

Board size, non-executive directors and CEO duality

Board size, board composition and CEO duality

Board size, Independent directors, CEO duality, institutional directors and ownership control.

Percentage of Return on assets as net profit to total Assets, Percentage of equity owned by the insiders to all equity of the firm, Board Audit Committee, Total assets of the firm and Total Sales of the firm.

Board size, independent directors, proportion of nonindependent and non-executive directors, director ownership, institutional ownership, public ownership, audit committee

meetings, and CEO compensation

Corporate governance compliance score

Board size, gender, CEO duality, education, board age, outside directors, board compensation and board's ownership

Ownership structure, board composition, board size, CEO duality and executive pay

Board size, independent directors, management ownership, foreign ownership, government ownership, auditing company

Corporate governance index

Governance ranking

$\mathrm{T} \& \mathrm{D}$ indices

Governance rating
Content analysis approach was used for this study. Content analysis is one of many research methods used for the analysis of data in the textual form. It is a technique which describes the words in a systematic way. It quantifies the textual data to be interpreted and analyzed. Graneheim and Lundman (2004) have said that "One of the most basic decisions when using content analysis is selecting the unit of analysis. One characteristic of qualitative content analysis is that the method, to a great extent, 
focuses on the subject and context, and emphasizes differences between and similarities within codes and categories."

The articles selected were coded for the identification of elements related to corporate governance and their relation to firm performance with the help of a software. Several codes were identified. Codes which were identified in only 1 or 2 articles were combined in a single code of "other codes". The list of codes for independent variables identified in the articles is given below:

1. Management Ownership

2. Firm Size

3. Foreign Ownership

4. Board Size

5. Leverage

6. Age of Firm

7. Board Composition

8. Institutional Ownership

9. Audit Committee

10. CEO Remuneration

11. Management Incentives

12. CEO Duality

13. Other Codes

Other codes include:

1. Governance ranking

2. Government as Shareholder

3. Auditing company

4. Ownership Information

5. Family Ownership

6. Corporate Governance Disclosures

7. Public ownership

8. Risk

9. Efficiency

10. Equity structure

11. Transparency

Identified codes were then analyzed for the patterns and relationships of independent corporate governance variables with firm performance. The summary of specific coded segments for each variable is given in Appendix 2.

\section{Limitations}

This study has covered only the studies which have been published in recent years. There could be long term patterns in the studies which were not identified in this study because of limitation of sample size and time span covered. Also, the results of these studies could be somewhat effected because of the aftereffects of financial crisis of 2008.

\section{Analysis and Conclusion}

In the discussion that follows, the main findings and insights from the content analysis are discussed. The discussion is divided in three sub-sections. First, the most frequently analyzed variables in each country are mentioned. Second, the findings about major variables are discussed. Finally, the main findings with respect to each country are elaborated.

\section{Most frequently studied variables}

The matrix of variables in the articles of all four countries are given in Appendix-1. The matrix of variables in Indian articles shows that board composition has been the most studied variable in recent years, having been the variable of interest in 7 out of 10 studies on corporate governance in Indian companies. In case of Russia, the most frequently studied variable has been firm size. As shown in Appendix-1, four out of five articles on Russian companies investigated the effect of firm size on the financial performance.

In the articles on Pakistani companies, the most studied variables of corporate governance are the board size and CEO duality. The effect of these two variables have been investigated in 8 out of 11 articles. The second most studied variable is board composition whose effect has been studied in 7 articles. The matrix of variables in Bangladeshi articles show that board size, board composition, management ownership and management incentives are the variables whose effect on firm performance have been studied the most. These variables have been studied in 4 out of 6 articles.

It can be observed from table 2 that the most studied variable in all the countries was board composition and the second most studied variable was board size which was followed by firm size and CEO duality.

Table 2

Number of times variables have been studied

\begin{tabular}{|c|c|c|c|}
\hline Variables & $\begin{array}{l}\text { No. of } \\
\text { times } \\
\text { studied }\end{array}$ & Variables & $\begin{array}{c}\text { No. of } \\
\text { times } \\
\text { studied }\end{array}$ \\
\hline Age of Firm & 7 & Firm Size & 16 \\
\hline $\begin{array}{c}\text { Audit } \\
\text { Committee }\end{array}$ & 10 & $\begin{array}{c}\text { Foreign } \\
\text { Ownership }\end{array}$ & 4 \\
\hline $\begin{array}{c}\text { Board } \\
\text { Composition }\end{array}$ & 19 & $\begin{array}{l}\text { Institutional } \\
\text { Ownership }\end{array}$ & 4 \\
\hline Board Size & 17 & Leverage & 13 \\
\hline CEO Duality & 13 & $\begin{array}{l}\text { Management } \\
\text { Incentives }\end{array}$ & 6 \\
\hline $\begin{array}{c}\text { CEO } \\
\text { Remuneration }\end{array}$ & 5 & $\begin{array}{c}\text { Management } \\
\text { Ownership }\end{array}$ & 7 \\
\hline
\end{tabular}

\section{Findings about Key Variables}

Analyses investigating the effect of age of firms on their financial performance have shown mixed results. In some studies, a positive association has been found between the age of the firm and its performance. But other studies show that age of the firms negatively affect the firm's performance i.e. the performance of firm decrease as the firms mature. Older firms should perform better than newer firms because of greater experience of the management and its reputation. On the other hand, newer firms sometimes bring a fresh breeze in the industry which leads to higher profitability because of their newer ways of conducting business and innovation as compared to older firms.

The code audit committee covers the variables audit committee size, audit committee independence as well as the number of meetings of audit committee. The result of the analysis shows that size of audit committee negatively effects the financial performance the firm. The independence of audit committee and number of audit committee meetings both affect the financial performance of the firm positively. The presence of audit committee is also positively related with firm's performance. However, one of the studies found a conflicting result. The independence of audit committee has a positive influence on firm performance because such committees can independently decide better courses of action and recommend better solutions without any pressure or influence from the executive directors. Similarly, with increased size of audit committee there is a possibility of conflict among the members of committee which could negatively affect the performance.

The code board composition includes the variables proportion of non-executive directors in the board, independence of board and the presence and ratio of female directors in the board. The analysis indicates that most studies found that the presence of female members on the board helps in the improvement of financial performance of the firm. However, one of the studies did not find any significant relationship between women on board and firm's performance. The analysis further shows that the presence of non-executive directors and independence of board have a negative effect on the performance of the firm. However, two studies found a positive effect of these variables on firm performance while two studies did not find a significant relationship. The reason for the negative impact of non-executive directors on the firm performance is that the non-executive directors might not have full commitment towards the goals and missions of the company and their other commitments might be a hindrance in their contribution.

Board size appears to have a positive and significant effect on firm performance. However, some studies found conflicting results as well, with six studies finding a negative relationship between board size and firm performance while one study found no significant relationship. Increased board size could help in the improvement of financial performance of the firm if there is diversity in the qualification and skills of the directors. However, the larger board size could affect the firm's performance negatively as larger number of directors could lead to conflicts among the board members and delayed decision making process. 
CEO duality is the condition where the position of CEO and chairman has been occupied by the same person. The results from recent studies show that CEO duality has a negative impact on the firm performance. This result is found because when both the higher positions of a firm are occupied by the same person, there is no check and balance of power and authority. Thus, the CEO duality can lead the CEO to make decisions as per his/her own will and personal interest rather than for the benefit of the organization. However, there were some conflicting results as well where CEO duality affected the firm performance positively. In favor of CEO duality, it could be argued that when CEO and chairman is the same person it could lead to optimal utilization of resources, better and quick decision making which could be beneficial for some companies.

$C E O$ remuneration affects the firm's profitability positively. Only one of the studies found conflicting results. When the remuneration of CEO is at a satisfactory level then the CEO would be more motivated to work, and would perform better. A satisfied and motivated CEO can lead the company towards betterment and thus, improves the financial performance of the firm.

The analysis shows that in most studies firm size has a positive effect on its performance. However, four studies found a negative relationship between firm size and performance but out of these four studies, there was an insignificant relationship determined in two studies. Firm size has a positive effect on its performance because larger the firm, more resources it has. Also, when a firm is larger in size and has larger assets, the banks and other loan granting authorities would be willing to authorize loans which in turn enables the firms to grow and start new ventures as well.

The effect of foreign ownership is positive on firm performance in all studies. As per this result, the foreign ownership improves firm performance and its reason could be that foreign owners bring a new mindset and fresh ideas in the organization. Foreign owners belong to different cultures and different mindsets and might have new ideas for the improvements of business which could lead to better firm performance. Institutional ownership has insignificant relationship with firm performance in all but one study. Only in one study there has been a significant and positive influence of institutional ownership on the firm performance. Leverage effects the firm performance negatively. However, three studies exhibited different results where a positive effect of leverage on firm performance was observed. Leverage is generally measured by debt equity ratio. The reason of decreasing firm performance because of increasing leverage is that with higher ratio of debt financing the amount of interest payable starts to increase as well. Increased interest expense directly effects the profitability of the firm negatively. On the other hand, the analysis suggested that positive effect of leverage on firm performance could be the reason of positive image of the firm. Potential investors might feel that if a company has a high leverage then it's because the company has a strong financial position and can sustain itself easily. This confidence of investors lead to better returns of the firm which leads to better financial performance.

A positive relationship between management incentives and firm performance has been observed in almost all the studies analyzed. In only one of the studies an insignificant effect of management incentives was observed on firm performance. Management incentives includes remuneration, bonuses and other monetary and non-monetary incentives. With the increase in management incentives, it could be argued that, directors feel motivated to work. When management incentives include performance based bonuses and incentives then directors would work more efficiently and effectively towards the achievement of those performance objectives. The achievement of performance objective by the management would lead to better profitability of the firm.

Management ownership has a positive and significant effect on firm performance in all the studies. However, one of the studies did not find a significant association between management ownership and firm performance. The reason of positive effect of management ownership on firm performance could be the alignment of objectives of other shareholders and management. When management becomes the owners of the company they have a personal interest in the growth and well-being of the company just like other shareholders. Management then works and looks towards the improvement of firm performance to increase shareholders return, as they would also benefit from this return being the owners of the company.

Family ownership effects firm performance positively in all the studies. Family ownership could improve firm performance as the decision-making process among the members of a single family is easy as compared to different individuals. This ease in decisionmaking process would lead to fast decisions leading to better performance. Also, the objectives of family members might be the same and aligned which could be difficult in case of different owners.

Government as shareholder has been studied in only two studies and both studies exhibited contrasting results. In one study, better performance was observed in the presence of government as a shareholder but in the other there was a negative effect on firm performance observed. The effect of risk on firm performance has been studied in three studies, all showing different results. One study did not find any significant relationship between risk and firm performance, the other found a positive relationship and the third one found a negative relationship between risk and firm performance.

The impact of corporate governance disclosure on the firm performance has been studied in two studies and both found a positive relationship among the two. Equity structure has been studied in two studies and both have found that it positively effects the firm performance. However, in one study the effect was insignificant although it was a positive effect.

The effect of public ownership and governance ranking has been in studied in one study and the effect of both these variables was positive on the firm performance. The variables efficiency, auditing company and ownership information have been studied in one study only. The relationship of all these variables with firm performance was found to be negative.

\section{Findings about Countries}

It is interesting to note that when in most of the studies firm size has positively affected the performance in Indian, Pakistani and Bangladeshi companies, Russia is the only country where in most studies the firm size has a negative impact on performance. There could be several reasons for this anomaly. This effect could be because of different governmental rules and regulations as well as country specific legal requirements for companies.

\section{References}

i. Ahmed, S. U., Ullah, G. W., Ahmed, S. P., \& Rahman, A. (2016). An Empirical Study on Corporate Governance and Islamic Bank Performance: A Case Study of Bangladesh. International Journal of Finance \& Banking Studies, 5(4), 1.

ii. Arora, A., Arora, A., Sharma, C., \& Sharma, C. (2016). Corporate governance and firm performance in developing countries: evidence from India. Corporate Governance, 16(2), 420-436.

iii. Bansal, N., \& Sharma, A. K. (2016). Audit committee, corporate governance and firm performance: empirical evidence from India. International Journal of Economics and Finance, 8(3), 103

iv. Bishnoi, T. R., \& Sh, S. D. (2015). Corporate Governance and Performance of Foreign Firms in India. Indian Journal of Corporate Governance, 8(2), 137-152.

v. Black, B. (2001). The corporate governance behavior and market value of Russian firms. Emerging Markets Review, 2(2), 89-108.

vi. Black, B. S., Love, I., \& Rachinsky, A. (2006). Corporate governance indices and firms' market values: Time series evidence from Russia. Emerging Markets Review, 7(4), 361379 .

vii. Brown, P., Beekes, W., \& Verhoeven, P. (2011). Corporate governance, accounting and finance: A review. Accounting and Finance, 51, 96-172.

viii. Cadbury, A. (2002), Corporate Governance and Chairmanship: A Personal View, Oxford

a. University Press, New York, NY. 
ix. Cheema, K. U. R., \& Din, M. S. (2013). Impact of corporate governance on performance of firms: A case study of cement industry in Pakistan. Journal of Business and Management Sciences, 1(4), 44-46.

x. Chughtai, M. W., \& Tahir, W. A. (2015). Effects of corporate governance on organization performance: evidence from banking sector of Pakistan. IOSR Journal of Business and Management, 17(3), 75-82.

xi. Claessens, S., \& Fan, J. P. (2002). Corporate govrenance in Asia: A survey. International Review of Finance, 3(2), 71103.

xii. Claessens, S., \& Yurtoglu, B. (2013). Corporate governance in emerging markets: A survey. Emerging Markets Review, 15, 1-33.

xiii. Dar, L., Naseem, M. A., Niazi, G. S. K., \& Rehman, R. U. (2011). Corporate governance and firm performance: A case study of Pakistan oil and gas companies listed in Karachi stock exchange. Global journal of management and business research, 11(8).

xiv. Ganiyu, Y. O., \& Abiodun, B. Y. (2012). The impact of corporate governance on capital structure decision of Nigerian firms. Research Journal in Organizational Psychology \& Educational Studies, 1(2), 121-128.

xv. Goel, P., \& Ramesh, R. S. (2016). Impact of Corporate Governance Practices on Firm Profitability: A study of Selected Industries in India. Journal of Finance, Accounting and Management, 7(2), 53.

xvi. Gohar, R., \& Batool, A. (2015). Effect of corporate governance on performance of microfinance institutions: A case from Pakistan. Emerging Markets Finance and Trade, 51(sup6), S94-S106.

xvii. Gul, S., Sajid, M., Khan, M. B., Bukhari, S. A., \& Iqbal, J. (2011). The relationship between corporate governance and firm performance (Evidence from Textile Sector of Pakistan). Asian Journal of Business and Management Sciences, 1(12), 45-53.

xviii. Gull, A. A., Saeed, A., \& Abid, A. (2013). Corporate governance and performance: An empirical evidence from textile sector of Pakistan. African Journal of Business Management, 7(22), 2112.

xix. Habib, M. A. (2016). Relationship between corporate governance and firm performance: a case study in Bangladesh.

xx. Hoque, M. Z., Islam, R. M., \& Ahmed, H. (2013). Corporate governance and bank performance: the case of Bangladesh.

xxi. Islam, J., Sathye, M., \& Hu, H. (2015). Examining the relationship between corporate governance and bank performance in Bangladesh. South African Journal of Business Management, 46(4), 43-52.

xxii. Khatab, H., Masood, M., Zaman, K., Saleem, S., \& Saeed, B. (2011). Corporate governance and firm performance: A case study of Karachi stock market. International Journal of Trade, Economics and Finance, 2(1), 39.

xxiii. Kirkpatrick, G. (2009). The corporate governance lessons from the financial crisis. OECD Journal: Financial Market Trends, 1, 61-87.

xxiv. Kumar, S. (2016). Corporate governance and firm performance in Indian listed it companies. Corporate Governance, 2(10).

xxv. Kumar, P., Kumar, N., Gupta, S. K., \& Sharma, R. K. (2017). Impact of Corporate Governance and Financial Parameters on Profitability of the BSE 100 Companies. IUP Journal of Corporate Governance, 16(1), 7.

xxvi. Kuznecovs, M., \& Pal, S. (2012). Does corporate governance reform necessarily boost firm performance? Recent evidence from Russia. xxvii. Latif, B. I. L. A. L., Shahid, M. N., Haq, M. Z. U., Waqas, H. M., \& Arshad, A. R. B. A. B. (2013). Impact of corporate governance on firm performance: Evidence from sugar mills of Pakistan. European Journal of Business and Management, 5(1), 51-59.

xxviii. Love, I., \& Rachinsky, A. (2015). Corporate Governance and Bank Performance in Emerging Markets: Evidence from Russia and Ukraine. Emerging Markets Finance and Trade, 51(sup2), S101-S121.

xxix. Lückerath-Rovers, M. (2013). Women on boards and firm performance. Journal of Management \& Governance, 17(2), 491-509.

xxx. Mohinder, S., \& Sanjeev, K. (2015). Case Study: Corporate Governance and Firm's Performance during Subprime Crisis: Evidence from Indian firms. Advances in Management, 8(12), 16.

xxxi. Muhammad, H., Rehman, A. U., \& Waqas, M. (2016). The effect of corporate governance practices on firm performance: Evidence from Pakistan. The East Asian Journal of Business Management, 6(1), 5-12.

xxxii. Narwal, K. P., \& Jindal, S. (2015). The impact of corporate governance on the profitability: An empirical study of Indian textile industry. International Journal of Research in Management, Science \& Technology, 3(2), 81-85.

xxxiii. Ng'eni, F. B. (2015). The corporate governance and firm performance: A review of existing empirical evidence. European Journal of Business and Management, 7(33).

xxxiv. Orazalin, N., Makarov, R., \& Ospanova, M. (2015). Corporate governance and firm performance in the oil and gas industry of Russia. Journal of Business Economics and Finance, 4(4).

xxxv. Pattanayak, M. (2008). Corporate governance, product market competition and firm performance in India: An empirical inquiry

xxxvi. Rajput, N. (2015). Shareholder types, corporate governance and firm performance: An anecdote from Indian corporate sector. Asian Journal of Finance \& Accounting, 7(1), 45.

xxxvii. Rashid, A. (2013). Corporate governance, executive pay and firm performance: Evidence from Bangladesh. International Journal of Management, 30(2), 556.

xxxviii. Rouf, D., \& Abdur, M. (2012). The financial performance and corporate governance disclosure: A study in the annual reports of listed companies of Bangladesh.

xxxix. Terjesen, S., Sealy, R., \& Singh, V. (2009). Women directors on corporate boards: A review and research agenda. Corporate Governance: An International Review, 17(3), 320-337.

xl. Weir, C., \& Laing, D. (2000). The performance-governance relationship: The effects of Cadbury compliance on UK quoted companies. Journal of management and governance, 4(4), 265-281.

xli. Yasser, Q. R. (2011). Corporate governance and performance (a case study for Pakistani communication sector). International Journal of Trade, Economics and Finance, 2(3), 204.

xlii. Yasser, Q. R. (2011). Corporate governance and performance: An analysis of Pakistani listed firms. Global Journal of Management and Business Research, 11(10)

xliii. Yilmaz, C., \& BuyukluI, A. H. (2016). Impacts of corporate governance on firm performance: Turkey case with a panel data analysis. Eurasian Journal of Economic and Finance, 4(1), 56-72. 


\section{Appendix 1}

Matrix of variables in Indian articles

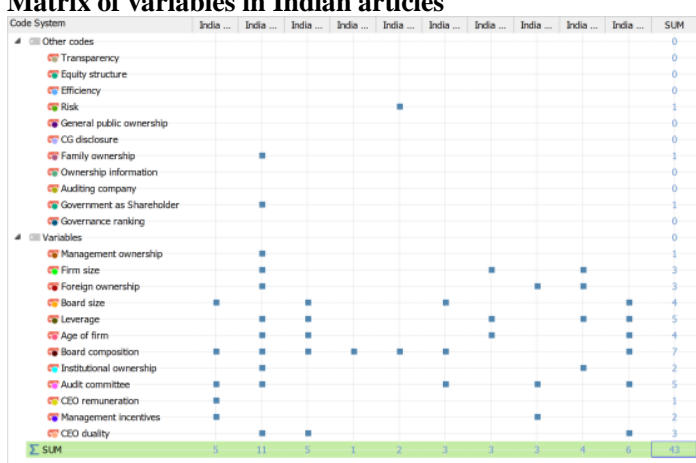

Matrix of variables in Pakistani articles

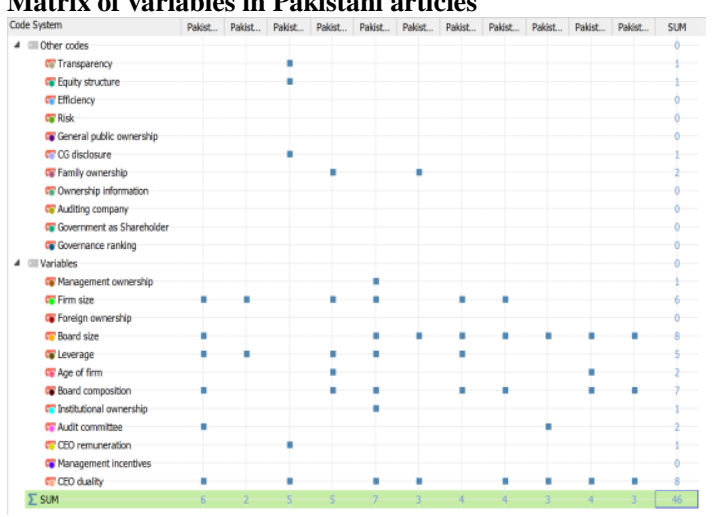

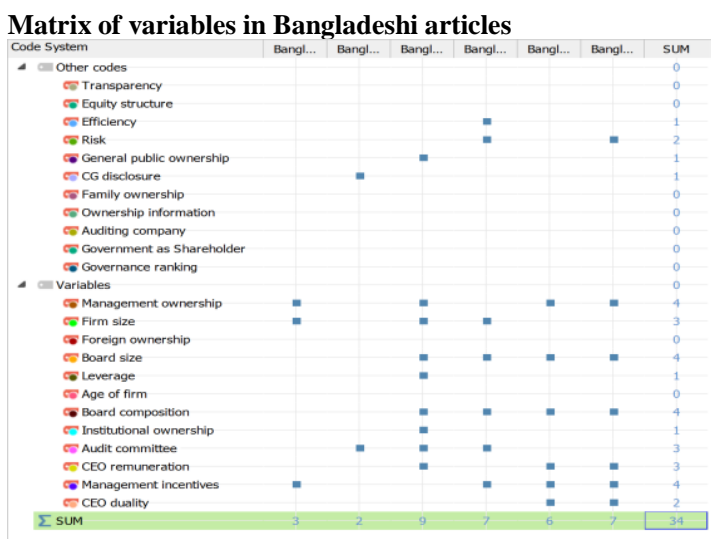

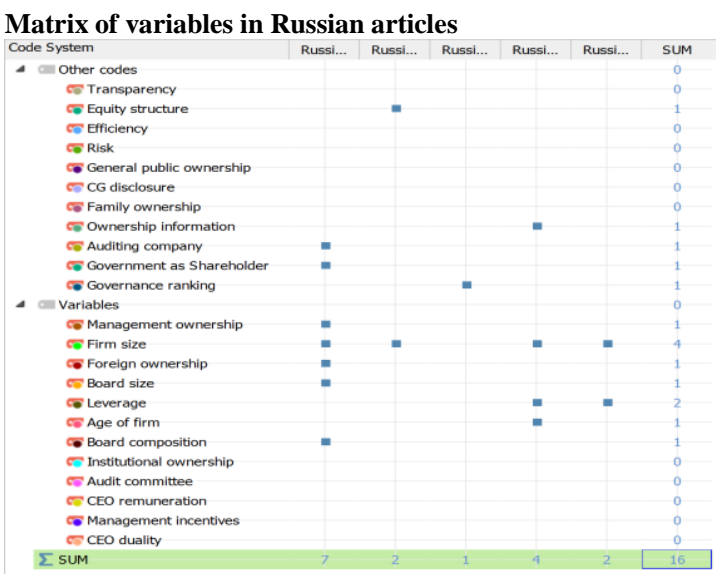

Appendix 2

\begin{tabular}{|l|l|}
\hline \multicolumn{1}{|l|}{ Age of Firm } & Segment \\
\hline Document & Firm age had a positive effect on performance \\
\hline India (2) & $\begin{array}{l}\text { The age of firm is negatively associated with TQ, implying that the new firms are performing comparatively } \\
\text { better. }\end{array}$ \\
\hline India (4) & Age show negative impact on RONW. \\
\hline India (8) & $\begin{array}{l}\text { Firm age exhibited the same relationship as was of Tobin 's Q. It seems that less mature firms are improving } \\
\text { their returns and their market price. }\end{array}$ \\
\hline India (11) & FAGE is negatively related with firm performance. \\
\hline Pakistan (4) & FA have a positive significant impact on ROA \\
\hline Pakistan (10) & firm performance is significantly better for older firms \\
\hline Russia (4) &
\end{tabular}

\begin{tabular}{|l|l|}
\hline Audit Committee & Segment \\
\hline Document & More audit committee members are significantly negative to the profitability of different textile firms \\
\hline India (1) & negative and significant impact of audit committee size \\
\hline India (2) & Most of the other parameters of corporate governance have no correlation with the performance parameters. \\
\hline India (7) & Audit index has significant positive relation with Return on Investments (ROI) \\
\hline India (9) & $\begin{array}{l}\text { degree of audit committee independence was found to play a positive and significant role in enhancing firm } \\
\text { performance in association with ROE }\end{array}$ \\
\hline India (11) & It also shows a positive relationship between firm performance (ROA \& ROE) and audit committee \\
\hline Pakistan (1) & There is a negative relationship between ROE, CEO status and audit committees but they have significant effect \\
\hline Pakistan (9) & $\begin{array}{l}\text { Positively correlated with return on equity at the 1\% level of significant. Similar results appear for the board } \\
\text { audit committee. }\end{array}$ \\
\hline Bangladesh (2) & increasing frequencies of audit committee meetings could significantly raise Bangladeshi bank's performance \\
\hline Bangladesh (3) & $\begin{array}{l}\text { The study also revealed that some corporate governance measures, such as audit committee, have no significant } \\
\text { effect on company performance }\end{array}$ \\
\hline Bangladesh (4)
\end{tabular}

\begin{tabular}{|l|l|}
\hline \multicolumn{2}{|l|}{ Board composition } \\
\hline Document & Segment \\
\hline India (1) & $\begin{array}{l}\text { Non-executive directors and board meetings positively influence the profitability but there is no significant } \\
\text { relationship with profitability }\end{array}$ \\
\hline
\end{tabular}




\begin{tabular}{|c|c|}
\hline India (2) & $\begin{array}{l}\text { Negative and significant impact of board meetings and presence of non-executive directors who may not have } \\
\text { total commitment to the cause of the company because of other commitments which limits their contribution. }\end{array}$ \\
\hline India (4) & The negative relationship between board independence and firm performance \\
\hline India (5) & $\begin{array}{l}\text { Two key variables are of main interest board diversity and board independence; these variables are main } \\
\text { variables responsible for the board effectiveness and hence for the firm value and shareholder value. The } \\
\text { empirical results for the period } 2008-2011 \text { show a positive relationship for both the variables. The study suggests } \\
\text { that number of women on board should be increased which may lead to improved firm performance. }\end{array}$ \\
\hline India (6) & $\begin{array}{l}\text { It has been observed that there is no significant relation between the individual parameters of corporate } \\
\text { governance and variables of financial performance }\end{array}$ \\
\hline India (7) & Most of the other parameters of corporate governance have no correlation with the performance parameters. \\
\hline India (11) & $\begin{array}{l}\text { a significant negative association was found between independence of board and performance of firm as } \\
\text { measured by return on assets, Tobin 's } q \text { and market capitalization (i.e. lesser the number of independent directors } \\
\text { on the board, better the firm performance) }\end{array}$ \\
\hline Pakistan (1) & it indicates a negative relationship between firm performance (ROA \& ROE) and board composition \\
\hline Pakistan (4) & higher proportion of independent directors leads to lower firm value \\
\hline Pakistan (5) & $\begin{array}{l}\text { The variable board composition or number of independent directors was found to have strong positive correlation } \\
\text { with firm performance. }\end{array}$ \\
\hline Pakistan (7) & $\begin{array}{l}\text { board size and non-executive director has insignificant relationship with the performance of the banks which } \\
\text { means that by increasing the member of board of director and maximum participation of non-executive director } \\
\text { in the board would be helpful in increasing the performance of the banks }\end{array}$ \\
\hline Pakistan (8) & financial performance is not affected by the presence of female members on the board of directors \\
\hline Pakistan (10) & NED's are found to have an unfavorable relationship with other dependent variables \\
\hline Pakistan (11) & $\begin{array}{l}\text { Board composition has insignificant impact on firm performance. It explains that when more independent } \\
\text { directors sit on the board, the firm's performance decreases. }\end{array}$ \\
\hline Bangladesh (3) & $\begin{array}{l}\text { Neither of the board composition variables -proportion of independent director (IND) and proportion of non- } \\
\text { independent non-executive director (NINE) is turned up to be significant in all the models }\end{array}$ \\
\hline Bangladesh (4) & $\begin{array}{l}\text { The study also revealed that some corporate governance measures, such as the proportion of independent } \\
\text { directors and independent supervisory directors have no significant effect on company performance }\end{array}$ \\
\hline Bangladesh (5) & $\begin{array}{l}\text { female board members, board's working experience, and board's compensation all have positive correlations } \\
\text { with firm's performance }\end{array}$ \\
\hline Bangladesh (6) & board composition has little role in influencing firm performance \\
\hline Russia (1) & independent directors on the board do not appear to affect firm performance \\
\hline
\end{tabular}

\begin{tabular}{|c|c|}
\hline \multicolumn{2}{|l|}{ Board size } \\
\hline Document & Segment \\
\hline India (1) & Large board size may not be in favor of Indian textiles firms because they do not increase the profitability. \\
\hline India (4) & The results show that board size is negatively related to ROA. \\
\hline India (7) & Board size is positively related with the sales growth \\
\hline India (11) & board size was found to be positively associated with all measures of firm performance \\
\hline Pakistan (1) & It shows positive relationship between firm performance (ROA \& ROE) and board size \\
\hline Pakistan (5) & board size which has a negative and significant influence on firm performance \\
\hline Pakistan (6) & board size does not affect the performance of a firm \\
\hline Pakistan (7) & $\begin{array}{l}\text { board size and non-executive director has insignificant relationship with the performance of the banks which } \\
\text { means that by increasing the member of board of director and maximum participation of non-executive director } \\
\text { in the board would be helpful in increasing the performance of the banks }\end{array}$ \\
\hline Pakistan (8) & $\begin{array}{lcclcccccc}\text { board size is negatively related } & \text { with } & \text { ROA; that } & \text { is, } & \text { large } & \text { board } & \text { has } & \text { a } \\
\text { negative influence on the economic and financial performance (ROA) }\end{array}$ \\
\hline Pakistan (9) & $\begin{array}{l}\text { There is a positive relationship between two Firm Performance Measures (ROE and PM) and Two Corporate } \\
\text { Governance Mechanisms (Board size \& AGM) but they have no significant effect }\end{array}$ \\
\hline Pakistan (10) & This study has unveiled an optimistic connection between board size and all performance related variables \\
\hline Pakistan (11) & Board size has significant impact on firm performance \\
\hline Bangladesh (3) & Board members are found to have positive and significant influence on bank performance measured by ROA \\
\hline Bangladesh (4) & $\begin{array}{l}\text { The study also revealed that some corporate governance measures, such as size of the board have no significant } \\
\text { effect on company performance }\end{array}$ \\
\hline Bangladesh (5) & board's size reduces firm's performance \\
\hline Bangladesh (6) & $\begin{array}{l}\text { Board size and firm risk have significant positive explanatory power in influencing firm performance under both } \\
\text { the performance measures }\end{array}$ \\
\hline Russia (1) & The board size does not appear to affect firm performance \\
\hline
\end{tabular}

\begin{tabular}{|l|l|}
\hline \multicolumn{2}{|l|}{ CEO Duality } \\
\hline Document & Segment \\
\hline India (2) & negative and significant impact of CEO Duality \\
\hline India (4) & $\begin{array}{l}\text { CEO duality is not found to be related to any performance measure; thus, it does not seem to be a crucial } \\
\text { determinant of firm performance }\end{array}$ \\
\hline
\end{tabular}




\begin{tabular}{|l|l|}
\hline India (11) & $\begin{array}{l}\text { Leadership structure of a firm or dual position occupied by CEO have strong positive association with firm } \\
\text { performance. This means that a single person acting as CEO as well as Chairman of the board majorly influences } \\
\text { optimum utilization of the assets and capital of the firm along with several other factors. }\end{array}$ \\
\hline there is a negative relationship between firm performance (ROA \& ROE) and CEO duality \\
\hline Pakistan (1) & $\begin{array}{l}\text { weak positive association were predominantly from 'Transparency and Disclosure' being: Separation of the } \\
\text { offices of the Chairman or Board and CEO }\end{array}$ \\
\hline Pakistan (5) & CEO-Chairperson duality with coefficient (-0.077) is negative and significantly correlated with firm performance \\
\hline Pakistan (6) & $\begin{array}{l}\text { CEO duality is negatively and so significantly related to cement industry } \\
\text { performance }\end{array}$ \\
\hline Pakistan (8) & CEO/chair duality has a negative significant association with ROA and OSS. CEO/chair duality decreases ROA \\
\hline Pakistan (9) & $\begin{array}{l}\text { There is a negative relationship between ROE, CEO status but they have } \\
\text { significant effect }\end{array}$ \\
\hline Pakistan (10) & $\begin{array}{l}\text { Empirical findings regarding duality are like prior researchers, unveiling a negative impact of duality on } \\
\text { performance } \\
\text { all performance components } \\
\text { by }\end{array}$ \\
\hline Pakistan (11) & CEO/Chairman Duality has a significant impact on ROA \\
\hline Bangladesh (5) & duality of the CEO has positive correlations with firm's performance \\
\hline Bangladesh (6) & CEO duality has no positive influence on firm performance. \\
\hline
\end{tabular}

\begin{tabular}{|l|l|}
\hline CEO Remuneration \\
\hline Document & Segment \\
\hline India (1) & director's remuneration has significant positive association with the profitability \\
\hline Pakistan (3) & $\begin{array}{l}\text { strong positive association chiefly included: Stability of Revenue stream and Profitability History, Positive } \\
\text { accumulated profits and reserves, Proportion of CEO's salary }\end{array}$ \\
\hline Bangladesh (3) & the result of negative effect of CEO compensation on performance \\
\hline Bangladesh (5) & board's compensation has positive correlations with firm's performance \\
\hline Bangladesh (6) & $\begin{array}{l}\text { There is a positive relationship between the executive pay and firm performance under all the performance } \\
\text { measures. }\end{array}$ \\
\hline
\end{tabular}

\begin{tabular}{|l|l|}
\hline \multicolumn{1}{|l|}{ Firm Size } & Segment \\
\hline Document & $\begin{array}{l}\text { Size has a significant and positive effect in increasing the ROE at } \\
\text { significance level. }\end{array}$ \\
\hline India (2) & the size of the company has the positive effect on the ROCE \\
\hline India (8) & $\begin{array}{l}\text { A positive and statistically significant relationship between firm size and } \\
\text { productivity. }\end{array}$ \\
\hline India (10) & firm size is positively related to the return on equity (ROE) \\
\hline Pakistan (1) & $\begin{array}{l}\text { Size has negative and insignificant relationship with ROA of the firm which shows that firms with greater size } \\
\text { has less ROA. }\end{array}$ \\
\hline Pakistan (2) & This research found FSIZE to be positively related to firm performance. \\
\hline Pakistan (4) & $\begin{array}{l}\text { Size and growth is positive and statistically significant showing the positive influence of these variables on firm } \\
\text { performance. }\end{array}$ \\
\hline Pakistan (5) & bank size shows positive and significant relationship \\
\hline Pakistan (7) & Firm size has positive effects on performance \\
\hline Pakistan (8) & There is significant relationship between ROA and Firm Size \\
\hline Bangladesh (1) & the size of banks (measured by total assets, TA) shows negative but insignificant effects on financial performance \\
\hline Bangladesh (3) & The sign of the relationship between bank performance and the size variable is positive for this study \\
\hline Bangladesh (4) & size is negatively associated performance \\
\hline Russia (1) & Size of firm is significant and positively related to ROA and ROE \\
\hline Russia (2) & Firm's size (measured by total assets) tend to lower firm performance \\
\hline Russia (4) & the firm size is negative, suggesting that larger firms have lower valuations relative to their assets \\
\hline Russia (5) & \\
\hline
\end{tabular}

\begin{tabular}{|l|l|}
\hline \multicolumn{2}{|l|}{ Foreign Ownership } \\
\hline Document & Segment \\
\hline India (2) & There is a positive and significant relationship between foreign ownership and firm performance. \\
\hline India (9) & The result suggests that firms with higher foreign ownership holding will have higher profitability. \\
\hline India (10) & a positive influence of foreign ownership (FOREIGN) on firm productivity \\
\hline
\end{tabular}




\begin{tabular}{|l|l|}
\hline \multicolumn{2}{|l|}{ Institutional ownership } \\
\hline Document & Segment \\
\hline India (2) & $\begin{array}{l}\text { The presence of institutional shareholders in a company has a positive but insignificant effect on the firm } \\
\text { performance }\end{array}$ \\
\hline India (10) & Institutional investors may not contribute to the enhancement of firm productivity. \\
\hline Pakistan (5) & institutional block holding have significant positive influence on firm performance \\
\hline Bangladesh (3) & INO does not show any significant effects on bank performance either of the estimators. \\
\hline
\end{tabular}

\begin{tabular}{|c|c|}
\hline \multicolumn{2}{|l|}{ Leverage } \\
\hline Document & Segment \\
\hline India (2) & leverage had a negative impact \\
\hline India (4) & $\begin{array}{l}\text { Leverage is found to be negatively related to ROA, implying that firms with low leverage are likely to perform } \\
\text { better. }\end{array}$ \\
\hline India (8) & Leverage share a significant negative relation with the RONW. \\
\hline India (10) & The effect of leverage (BORROW) on firm productivity as negative. \\
\hline India (11) & Leverage was negatively and significantly related to all performance measures except Tobin 's Q \\
\hline Pakistan (1) & the control variable leverage is negatively related to the return on equity (ROE) \\
\hline Pakistan (2) & $\begin{array}{l}\text { The positive relationship of leverage and growth with ROA shows significant effect in measuring performance } \\
\text { of the firm. }\end{array}$ \\
\hline Pakistan (4) & DEBT is negatively related with firm performance. \\
\hline Pakistan (5) & leverage has negative influence on firm performance \\
\hline Pakistan (7) & Leverages show negative but significant relationship. \\
\hline Bangladesh (3) & $\begin{array}{l}\text { financial leverage' (measured by debt-equity ratio, DEQ) is found to have significant positive effects on } \\
\text { Bangladeshi banks when their performances are measured by ROE and Tobin's Q. }\end{array}$ \\
\hline Russia (4) & leverage (calculated as the ratio of liabilities to assets) tend to lower firm performance \\
\hline Russia (5) & $\begin{array}{l}\text { The leverage results are strongly positive and somewhat puzzling. It could be that in Russia high leverage plays } \\
\text { an informational role suggesting that the firm is "good enough" (or well-connected) to be able to obtain bank } \\
\text { finance }\end{array}$ \\
\hline
\end{tabular}

\begin{tabular}{|l|l|}
\hline \multicolumn{2}{|l|}{ Management Incentives } \\
\hline Document & Segment \\
\hline India (1) & director's remuneration has significant positive association with the profitability \\
\hline India (9) & $\begin{array}{l}\text { Remuneration Index has significant positive relation with Return on Investments (ROI) during pre-subprime } \\
\text { crisis periods. }\end{array}$ \\
\hline Bangladesh (1) & There is significant relationship between ROA and Director Fees \\
\hline Bangladesh (4) & The study also revealed that managers' incentives has no significant effect on company performance \\
\hline Bangladesh (5) & board's compensation has positive correlations with firm's performance \\
\hline Bangladesh (6) & $\begin{array}{l}\text { there is a positive relationship between the executive pay and firm performance under all the performance } \\
\text { measures. }\end{array}$ \\
\hline
\end{tabular}

\begin{tabular}{|l|l|}
\hline \multicolumn{2}{|l|}{ Management Ownership } \\
\hline Document & Segment \\
\hline India (2) & The effect of owner identity on firm performance exists and varies among different types of owner \\
\hline Pakistan (5) & Insider block holding did not appear to have any significant influence on firm performance. \\
\hline Bangladesh (1) & There is significant relationship between ROA and Ownership Control \\
\hline Bangladesh (3) & SDO exerts significant positive effects only in market based performance \\
\hline Bangladesh (5) & board's ownership will contribute positively to firm's performance \\
\hline Bangladesh (6) & director ownership has significant positive explanator \\
\hline Russia (1) & management ownership has a significant and positive relationship with ROA \\
\hline
\end{tabular}

\begin{tabular}{|l|l|l|}
\hline Other Codes & Variables & Segment \\
\hline Document & Family ownership & $\begin{array}{l}\text { family ownership has a positive and significant impact on the financial } \\
\text { performance of the company }\end{array}$ \\
\hline India (2) & \\
\hline
\end{tabular}




\begin{tabular}{|c|c|c|}
\hline Pakistan (4) & Family ownership & Family-controlled companies have better firm performance. \\
\hline Pakistan (6) & Family ownership & family owned cement firms have high profitability \\
\hline India (2) & $\begin{array}{l}\text { Government as } \\
\text { Shareholder }\end{array}$ & $\begin{array}{l}\text { There is a significant negative relationship between government ownership and } \\
\text { firm performance. }\end{array}$ \\
\hline Russia (1) & $\begin{array}{l}\text { Government as } \\
\text { Shareholder }\end{array}$ & better performance with the presence of the government as a shareholder \\
\hline India (6) & Risk & $\begin{array}{l}\text { It has been observed that there is no significant relation between the individual } \\
\text { parameters of corporate governance and variables of financial performance }\end{array}$ \\
\hline Bangladesh (4) & Risk & The risk variable is negatively related to performance \\
\hline Bangladesh (6) & Risk & $\begin{array}{l}\text { firm risk has significant positive explanatory power in influencing firm } \\
\text { performance under both the performance measures }\end{array}$ \\
\hline Pakistan (3) & CG disclosure & $\begin{array}{l}\text { Return on Equity had a positive association with } 7 \text { of the } 40 \text { CGSI factors (i.e. } \\
18 \% \text { ). These seven were predominantly from 'Equity Structure and Transparency } \\
\text { \& Disclosure }\end{array}$ \\
\hline Bangladesh (2) & CG disclosure & $\begin{array}{l}\text { Profitability of the firm is positively correlated to the level of corporate governance } \\
\text { disclosure (CGD). }\end{array}$ \\
\hline Pakistan (3) & Equity structure & $\begin{array}{l}\text { Return on Equity had a positive association with } 7 \text { of the } 40 \text { CGSI factors (i.e. } \\
18 \% \text { ). These seven were predominantly from 'Equity Structure and Transparency } \\
\text { \& Disclosure }\end{array}$ \\
\hline Pakistan (3) & Transparency & $\begin{array}{l}\text { Return on Equity had a positive association with } 7 \text { of the } 40 \text { CGSI factors (i.e. } \\
18 \% \text { ). These seven were predominantly from 'Equity Structure and Transparency } \\
\& \text { Disclosure }\end{array}$ \\
\hline Bangladesh (3) & Public ownership & 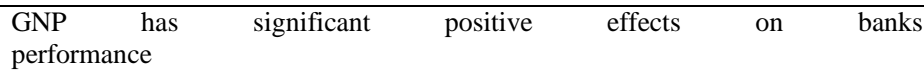 \\
\hline Bangladesh (4) & Efficiency & The efficiency variable has a negative relationship with performance \\
\hline Russia (1) & Auditing company & auditing company is negatively associated with firm performance \\
\hline Russia (2) & Equity structure & Own capital has insignificant but positive relationship with ROA \\
\hline Russia (3) & Governance ranking & improvement in governance ranking predicts an increase in firm value \\
\hline Russia (4) & $\begin{array}{l}\text { Ownership } \\
\text { information }\end{array}$ & $\begin{array}{l}\text { greater transparency with respect to ownership information generates a negative } \\
\text { impact on EBIT based firm performance measure }\end{array}$ \\
\hline
\end{tabular}

